\title{
Toward Mobile-Assisted Language Learning (MALL): Reaping Mobile Phone Benefits in Classroom Activities
}

\author{
Rully Agung Yudhiantara \\ UIN SGD Bandung \\ rully.agung@uinsgd.ac.id \\ Ihsan Abdul Nasir \\ UIN SGD Bandung \\ insan@uinsgd.ac.id \\ DOI: http://dx.doi.org/10.18326/rgt.v10i1.12-28
}

\section{ENGLISH ABSTRACT}

Mobile phone has been studied by researchers in its connection with education-related activities. This study was aimed at investigating: 1) students' perception toward mobile phone to support classroom activities; 2) students experience in using mobile phone use to support classoom activities. This study employed qualitative method. To collect the data, two methods were used namely: questionnaire and observation. Subjects participated in this study were 70 students. Findings showed that students had positive perception and attitude toward mobile phone to support classroom activities. In classroom they used mobile phone to support classroom activities. Reading e-books that support Phonology subject, playing audio and video file to get visualization of Phonological concept, operating offline dictionary to solve vocabularies were examples of classroom activities supported by mobile phone use.

Keywords: classroom activities, language learning, mobile phone, mobile-assisted language learning

\section{INDONESIAN ABSTRACT}

Kegiatan pendidikan khususnya pembelajaran bahasa dengan bantuan telepon seluler sedang banyak dikaji oleh peneliti. Penelitian ini bertujuan untuk menginvestigasi: 1) persepsi dan sikap mahasiswa terhadap penggunaan mobile phone untuk mendukung kegiatan belajar di kelas; 2) penggunaan mobile phone untuk keperluan mendukung kegiatan pembelajaran di kelas? Penelitian ini menggunakan metode kualitatif. Untuk mengumpulkan data, digunakan beberapa teknik yaitu: kuesioner dan observasi. Hasil temuan menunjukan bahwa mahasiswa mempunyai persepsi yang baik terhadap penggunaan mobile phone di kelas. Di kelas mahasiswa menggunakan mobile phone untuk keperluan kegiatan belajar di kelas. Membaca e-book untuk keperluan mata kuliah Phonology, menggunakan video dan audio untuk menonton materi pembelajaran serta menggunakan kamus offline adalah beberapa kegiatan yang menunjukan mahasiswa menggunakan mobile phone untuk keperluan belajar di kelas.

Kata kunci: kegiatan belajar di kelas, mobile phone, pembelajaran Bahasa 


\section{INTRODUCTION}

Education always gets benefits from information and communication technology (ICT) since students and teachers are always assisted by the current technology that support their classroom activities. Improvement in teaching can be achieved through ICT (Kee \& Samsudin, 2014). Modern technology has provided many inventions for human life. In communication field, mobile phone has played pivotal role in shaping our life and it goes without saying that education will try to reap its benefits.

Internet, used to be accessed through personal computer, can be operated through mobile phone and this allows students who are mostly at their teen and youth period to go online anywhere and anytime (Lenhart, 2015). Compared to personal computer, Mobile phone has been primarily used by teens to access internet (Madden, Lenhartm, Duggan, Cortesi, \& Gasser, 2013).

Several features are offered by mobile phone to its users and one of the features is texting. It helps people to interact anywhere and anytime for communication purposes regardless time and place. This is what teacher and students, as mobile phone users, need to explore its features in order to boost their learning process. This is likely to happen since the collaboration among teacher and student will be maintained through messaging or texting service from mobile phone (Looi, Seow, Zhang, So, Chen, \& Wong, 2010). In addition to communication maintenance between students and teacher as mobile phone benefit, Some studies found that texting has improved students's vocabulary and reading skill of students learning English (Plester, Wood, \& Joshi, 2009). These benefits exhibit how mobile phone supports communication and vocabulary enrichment in English learning context.

In addition to texting feature, Other features and function that mobile phone offers have been studied. One of the features that mobile phone offers is texting. It helps people to interact anywhere and anytime. This is what teacher and students need to boost their learning process since the collaboration will be maintained through this promising application (Looi, Seow, Zhang, So, Chen, \& Wong, 2010). Some studies found that texting has improved students's vocabulary and reading skill of students (Plester, Wood, \& Joshi, 2009). Feature of texting helped students vocabulary and reading skill (Plester, Wood, \& Joshi, 2009). This is what teacher and students need to boost their learning process since the collaboration will be maintained through this promising application (Looi, Seow, Zhang, So, Chen, \& Wong, 2010). 
Another feature that mobile phone always advertises and boasts is camera feature. This feaature can serve as a powerful tool for educational activities in terms of reading and writing assistance (Bull \& Thompson, 2004). Since mobile phone offers camera, it helps users to record and take picture any object they need especially for learning purposes. This function has been attracting teacher and students to use it in supporting classroom activities. this is to say that camera feature can be used by the students to collect data in their learning process. In language and art faculty, camera functioned to assist reading, witing and visualizing (Bull \& Thompson, 2004).

Mobile phone has also feature that entertain users to play music and video. This feature is classified as audio and video feature. For educational purposes, the feature can help students to create and explore podcast for learning. studies showed that this feature when used for podcast learning project improved students' motivation and their higher order thinking in reading, writing and listening skill when learning English (Smythe \&Neufeld, 2010). Seizing feature of audio video for podcast project was proven to be helpful device in improving English language learners (ELL) in terms of their language skills (Gromik, 2012). It can be concluded that mobile phone with its features has the ability to play audio file which can be used to help English learning language.

In a nutshel mobile phone which offers texting, camera, audio and video recorder has no doubt given benfit for students in learning process (Thomas \& Munoz, 2016). In addition to the benefits that mobile phone offer mentioned earlier, there are many benefits that teacher can gain by using mobile phone for teaching and learning activities. Liu (2015) found that teacher could provide differentiated learning pathways for students, offered multiple modality for students to produce their protfolio, supported students improvisation and learning creation (Liu, Scordio, Renata, Navarete, Yujung, \& Lim, 2015). Mobile phone goes beyond its basic features if teacher and students can seize its feature and function for educational purposes.

Mobile phone with all its supporting features has allowed teachers to personalize instruction (Steel, 2012). It is the teachers with their creativity that make possible for personalizing instruction to achieve objective of instruction. The need to collaborate between students and teacher and among students can be facilitated by mobile phone since there are many applications that support the collaboration (Corbeil \& Valdes Corbeil, 2007). Personalizing instruction and facilitating collaboration can be achieved by means of mobile 
phone. It goes without saying that teachers and students are challenged to explore and seize mobile phone benefit for classroom activities.

Sha (2012) found that students got benefit from mobile phone for their learning purpose. They gained benefit by using mobile phone for learning activities because they had the opportunities to regulate their progress in learning activities. This benefit might provide additional value for student to organize their learning need (Sha, Looi, Chen, \& Zhang, 2012).

In the same vein, Al-Fahd (2009) investigated students' readiness to use their mobile phone for learning purpose. Students as the users of mobile phone showed their readiness to integrate mobile phone in classroom activities. They had positive attitude, perception and attitude in using mobile phone for mobile learning (Al-Fahd, 2009). Since mobile phone is mobile gadget in nature, it meets the demand of students need for communication. Students always carry mobile phone for their daily activities and this is the most contributing factor to integrate mobile phone for classroom- related work. Their availability and mobility really matter and they need to be explored for learning purposes (Pegrum, Oakley, \& Faulkner, 2013).

Studies on the effectivenes of mobile phone application for classroom activites have been well-documented. Mobile phone use in classroom improved students learning process in K-12 school level (Liu, Scordio, Renata, Navarete, Yujung, \& Lim, 2015). Mobile phone use in terms of texting function has been studied. Study showed that using messaging service increased classroom interactivity among teachers, students and faculty staff (Markett, Sanchez, Weber, \& Tangey, 2006).

Mobile phone has been proven to bring benefit for students. They can access educational content or e-book and textbook through their mobile phone anywhere and anytime. It is very likely that mobile phone has the power to promote the so-called ubiquitous learning. Students in university can learn anywhere and anytime as long as they bring their mobile devices that they operate and access for learning and it goes without saying that this promotes the trend of ubiquitous learning (Lee, Lee, \& Kweon, 2013).

Previous studies on using mobile phone in the classroom and outside classroom had been conducted. Khabiri (2013) reported mobile phone use practices among Iranian EFL learners. The study found that mobile phone offered many promising features that can be tailored for students' learning process (Khabiri \& Khatibi, 2013 ). In Nigeria a study conducted by Oyewusi (2014) found that mobile phone was able to promote students' reading 
habit. The study suggested that mobile phone should be designed appropriately with its supporting application in order to be able to promote students' reading habit (Oyewusi \& Ayanlola, 2014). Kee and Samsudin (2014) conducted research on mobile phone use for educational activities in Malaysia. The findings showed that student had positive perception and attitude toward mobile phone use for learning anytime and anywhere (Kee \& Samsudin, 2014).

However Studies investigating the use of mobile phone in Indonesian Islamic higher education institution are still relatively rare in the literature. This study aims at filling the gap and it tries to investigate how to tailor mobile phone to support classroom activities as an effort toward MALL. Specifically this study seeks to explore students' perception of mobile phone use to support classroom activities and how they engage in the mobile phones use during classroom activities. The specific research questions that guided the study are as follows:

(1) What are students' perception concerning their mobile phone to support classroom activities?

(2) How do students use mobile phone to support classroom activities?

\section{METHODS}

This study is qualitative in nature and it applied case study. The method was aimed at investigating students' perception on mobile phone use and their experience in using mobile phone to support classroom activities. To collect data, this study applied questionnaire and observation. The study involved 70 participants: 55 female students and 15 male students. They were students of English education department at UIN Sunan Gunung Djati Bandung and they took Phonology subject.

\section{Data Collection and Analysis}

The first research question deals with students' perception toward mobile phone use to support classroom activities. To answer research question one, this study employed questionnaire and observation. Questionnaire had been prepared to investigate students perception on mobile phone. Items in the questionnaire served to seek answer on the 
following information: time of purchasing mobile phone; brand and product of mobile phone; function students performed when using mobile phone and apps students used to support classroom activities.

Observation was conducted to investigate how students engage in using mobile phone to support classroom activities. The teacher acted as researcher and he collected data through one semester. In the first meeting students were told that they will fill in questionnaire on mobile phone use. In the following meeting, teacher asked students to participate in using mobile phone for classroom activities. For this purpose, teacher had prepared and given ebook, audio and video material that can be accessed through their mobile phone.

The data gathered were analysed qualitatively to answer research questions. Data from questionnaire and observation were described, categorized and interpreted to answer the research questions in this study. Triangulation was applied to enhance the validity and support sound conclusion in this study.

\section{DISCUSSION}

This study was aimed at investigating students' perception and attitude toward mobile phone and exploring students' experience in using mobile phone to support their classroom acitivity. There were two types of data that will be described in this section namely data from questionnaire and observation. Questionnaire data will be first described in this section to investigate students perception on their mobile phone to support classroom activties.

\section{Students' Perception of Mobile Phone}

There are four items constructed in the questionnaire to fill in by the students. Questionnaire were designed to explore information concerning students' purchase of their mobile phone, brand of their mobile phone, function they performed and application they used to support learning process. Here are the findings gained from questionnaire:

1. When did you purchase your mobile phone?

\begin{tabular}{|l|l|l|l|}
\hline No & Year of purchasing & Number of purchasing students & Percentage \\
\hline 1 & 2016 & 44 & $63 \%$ \\
\hline 2 & 2015 & 11 & $16 \%$ \\
\hline 3 & 2017 & 5 & $8 \%$ \\
\hline
\end{tabular}




\begin{tabular}{|l|l|l|l|}
\hline 4 & $2010-2014$ & 10 & $13 \%$ \\
\hline & Total & 70 & $100 \%$ \\
\hline
\end{tabular}

This data shows that students had their own mobile phone. In terms of purchasing time, there are three categories. The highest number of students purchasing time belonged to year 2016 because there were 44 students or $63 \%$ who bought their mobile phone that year. The lowest number of mobile phone purchase went to year 2017 since there were only five students or $8 \%$ bought their mobile phone that year. Based on the above table it can be seen that the oldest period of mobile phone purchase happened in 2010-2014. In other words some student used their mobile phone that they had bought last four-five years ago. It goes without saying that students need and treat their mobile phone as their basic need that they need to fulfill by owning mobile phone. They belong to digital natives who are closely associated with mobile phone.

\section{What brand of mobile phone did you purchase?}

\begin{tabular}{|l|l|l|l|}
\hline No & Type of responds & Units & Percentage \\
\hline 1 & Samsung & 20 & $28.5 \%$ \\
\hline 2 & Oppo & 14 & $20 \%$ \\
\hline 3 & Asus & 8 & $11.4 \%$ \\
\hline 4 & Other brands & 28 & $40 \%$ \\
\hline & Total & 70 & $100 \%$ \\
\hline
\end{tabular}

This data shows that there were various brands of mobile phone that students own. Coming at the top was Samsung brand with 20 students or 28,5\% using it. Rank 2 and 3 respectively belonged to Oppo and Asus. Several brands consituted 28 units. In this table, the ownership of mobile phone was dominated by Samsung brand. It was clear that this brand was successful IN Indonesia to persuade youths to buy it since it offers high quality and strong brand.

Students have various option to buy mobile phone since there is a high competition among mobile phone manufacturers. This condition is beneficial for customers especially students. With affordable prices, they can purchase any mobile phone they want. All that students need is that the capacity and feature that they can operate to explore mobile phone. This is to say that brands of mobile phone is not their concern, function and apps do matter.

3. What function do you frequently perform when using mobile phone? 


\begin{tabular}{|l|l|}
\hline No & Functions students perform when using mobile phone \\
\hline 1 & Chatting (WA, Line, BBM etc) \\
\hline 2 & Social Media (Facebook, Instagram, Twitter) \\
\hline 3 & Browsing \\
\hline 4 & Others (game, Music, selfie...) \\
\hline
\end{tabular}

When it comes to functions of using mobile phone, students wrote several main functions of their mobile phone namely: chatting, social media, browsing and other apps. This findings shows that mobile phone has been excessively used for communication or chatting purpose. Several apps are available to support and meet their need for chatting.

Social media was performed by students from their mobile phone. Gone are the days when social media like facebook are operated through computers. Digital natives have mobile phone that can operate social media. Another function is browsing. Students do not need their computer in order to browse something they want to know. Mobile phone has taken the role of computer in delivering information by means of browsing. Students use their mobile phone to browse instead their computer.

\section{What apps do you use to support learning?}

\begin{tabular}{|l|l|}
\hline No & Apps students used to support learning \\
\hline 1 & offline dictionary \\
\hline 2 & e-book/ pdf material \\
\hline 3 & other learning apps \\
\hline
\end{tabular}

To respond the question number 4, students wrote some apps that support their learning activity. Offline dictionary, ebook material and other learning apps were used to support their learning. This findings show that mobile phone is open to explore for learning purpose. Students used their mobile phone to access offline dictionary in order to learn English. PDF reader was also supporting tool for students to facilitate learning. there are various book, article and files that can be run in pdf format. These file can be accessed by students from their mobile phone.

\section{How Students Use Mobile Phone to Support classroom activities}

This data was collected to answer research question concerning students' experience in using mobile phone for classroom-related activities during classroom observation. There were 
several findings in terms of students experience in using mobile phone for classroom activities.

\section{1. offline dictionary use}

The teacher prioritized this application to be investigated first from their mobile phone. He checked some students' mobile phone to check whether or not offline dictionary installed. Students, some felt proud, showed their offline dictionary installed in their mobile phone to convince the teacher concerning the application. This was important for the study since students had supporting tool available in their mobile phone to support classroom activities.

Since offline dictionary was installed in their mobile phone, there are many learning activities that could be facilitated. Based on the observation, teacher foud out that many students had installed the apps in their mobile phone. One interesting opinion expressed by the student as can be seen in the dialog excerpt as follows:

Teacher: "Why did you install this offline dictionary in your mobile phone?"

Student: "I need this offline dictionary installed in my mobile phone sir, so I can read it anywere and anytime."

To reap the benefit of offline dictionary, the teacher had designed the activity where looking up dictionary was implemented. He had some vocabularies from each unit of Phonology course that required students to look up their dictionary. Since those vocabularies were new and they had no previous knowledge on those vocabularies, they had to access their mobile phone to look up their offline dictionary in dealing with words they did not know.

In each meeting, teacher asked students to look up dictionary everytime they encounter new word. Students used their mobile phone with the instruction from teachers. On other occasion they opened dictionary for group project and individual inquiry. They were encouraged to actively use their mobile phone for vaocabulary enrichment. They found mobile phone helpful in providing tool that they need in searching for meaning of particular word during their learning activities in the classroom.

\section{Pdf reader app (e-book) use}

This application was important to make sure that the course enabled the students to access material. Mobile phone can run this application to help users read files that they usually run in their computer. The teacher prepared and shared e-book and file in form of Pdf that can be operated in students mobile phone. Some students who had not installed pdf reader in their mobile phone, downloaded the application and installed it in theirs. 
The teacher prepared and shared e-book material that can be operated in students' mobile phone. Since students' mobile phone had PDF Reader inside, it was easier for students to read and display their learning material. Both students and the teacher used mobile phone to read the e-book and learning material from their mobile phone.

From meeting three to last meeting, student and teacher run the application to access the file, read and discuss the file shown in their mobile phone. The teacher in many occasions suggested students to read the material outside classroom to prepare before the meeting in the classroom.

In some meetings, the teacher investigated their opinion concerning the use of mobile phone in accessing their material through mobile phone. Using pdf reader to access material in their phone might provided them different experiences compared to using computer. The teacher investigated students' opinion concerning e-book that students operated through mobile phone. There were several comments that students expressed to show their support in using mobile phone to read e-book for their learning material. One of the examples can be seen from the excerpt below:

Teacher: "What is your opinion about using mobile phone to read e-book?"

Student: "This is paperless way of learning sir, mobile phone really helpful to facilitate learning. I love this sir."

This comment clearly expressed students' support for using mobile phone in classroom activities. Students viewed mobile phone as supporting tool that facilitated students in accessing material they were learning in the classroom. It was easier for student to carry mobile phone everywhere they go and they could read the material everywhere. This condition showed that mobile phone supported learning activities in the classom. In addition the teacher also suggested students to read the ebook material outside classroom. This is to promote the so called mobile-assisted language learning (MALL).

\section{Audio video player use}

This third feature built in mobile phone was investigated in this study. To design the classroom activities using audio video inside mobile phone, the teacher provided students audio video file. These audio video files were supporting material and they were complementary to the course of Phonology. They consisted of video explaining vowel, consonant sound and etc. 
The teacher prepared and shared audio and video material that support the e-book in phonology course. Since Students' mobile phone has supporting apps to play audio and video, it was easier for them to play the files they got from the lecturer in Phonology course. This audio video player was really important for students as an effort to understand some material that need to be visualized from Phonology concept. To show how students were happy because they got visualization from the video, the dialog excerpt below can illustrate:

Teacher: "How helpful is the video to explain the concept?"

Student: "I find the concept confusing when reading e-book, but this video helps me to understand easily the concept. My mobile phone is useful to support my learning process."

It was very clear that their mobile phone was very helpful to deliver audio video file that helped students to understand the material. There were some video material that students needed to play in their mobile phone and sure they could play it in the classroom and outside classroom. The findings showed that students seized their mobile phone to support learning activities in classroom.

\section{Audio video recorder use}

This feature was useful in assisting students to produce their project in classroom. to achieve this objective, the teacher assigned students projects that showed their understanding in the subject matter. This projects should be accomplished by using their mobile phone offerring the audio video recorder. This application helped student to produce their project.

Students worked in group and they used their mobile phone to accomplish their project. They demonstrated in their video project concerning their knowledge and on consonant and vowel and other topics learned in several meeting. Their mobile phone were capable of producing quality video to accomplish their project. Even though their devices were not professional device, they could accomplish their project by using their mobile phone. One of the comment is as follow:

Teacher: "is mobile phone helpful to produce the project?"

Student: "yes it is. Even though it is not professional device, it helped us to create the video project"

The statement clearly supported that mobile phone supported classroom activities and learning process. Students used their mobile phone to demonstrate their knowledge and undertanding about the course by creating video project by the mean of mobile phone. 
The results indicated that each student had their mobile phone. It goes without saying that mobile phone ownership among youth is high. This is in line with the previous findings that students in higher education are incresingly using mobile phone to access internet (Kennedy, 2014). Many mass media reported the successful sale of mobile phone in Indonesia. It can be concluded that youth customer is the largest customer of mobile phone. The findings in this study confirmed the previous research by Lenhart (2015) that teens and youth are the largest customer of mobile phone and they have used their mobile phone to go online. Since they are digital natives they need mobile phone to fulfill their need (Prensky, 2001).

Based on the observation, the teacher knew that students spent their time mostly in using social media. There were two main functions student performed when accessing mobile phone. Given the internet access, they put chatting and social media as their core function to acces mobile phone. Some studies found that social media is the most frequently visited and accessed platform when using internet by teen and youth. They prefereed to use their mobile phone compared to computers when accessing social media (Madden, Lenhart, Duggan, Cortesi, \& Gasser, 2013). If designed appropriately, this connectivity and mobility of mobile phone and internet can promote mobile-assisted language learning (Ducate \& Lomicka, 2013).

Students had installed in their gadget offline dictionary. This app was the most frequently installed app in students' mobile phone that they usually use to support learning. It goes without saying that mobile phone has promoted the learning of vocabulary for students (Nisbet \& Austin, 2013). Other apps they use is PDF Reader for operating e-book. This apps was useful app for students to read e-book and other reading materials. This findings confirmed previous studies that features in mobile phone help students learn reading, vocabulary (Plester, Wood, \& Joshi, 2009). In other words mobile phone when used approriately may build reading habit among students (Oyewusi \& Ayanlola, 2014).

From observation, students seemed to enjoy the ease and portability of mobile phone that helped them learn in classsroom. They found it more practical to use mobile phone compared to notebook in classroom activites (Lenhart, 2015). Mobile phone served as a learning tool in the 21 st century and it call for teachers creativity to tailor mobile phone for classroom activities (Kee \& Samsudin, 2014). 
In classroom students used their mobile phone to play audio video material. Without difficulties, students could access and play their files in their mobile phone. According to their opinion, it was clear that feature of audio video player in their mobile phone helped them in learning proces as the previous research had proven (Smythe \& Neufeld, 2010).

Collaboration among students and teachers had been shown in this study. Video project was facilitated by the use of mobile phone. In other words mobile phone helped student to produce their portfolio in order to demonstrate their achievement in learning (Liu, Scordio, Renata, Navarete, Yujung, \& Lim, 2015).

Students were ready to integrate their mobile phone in classroom activities. Their mobile phones were equipped with application that facilitated them to support learning in classroom. Since they belong to digital natives they face no problem and difficulties to use mobile phone for classroom activities (Pegrum, Oakley, \& Faulkner, 2013)

Mobile phone in this study facilitated students to learn Phonology. It stores files of pdf that students could access when they needed to read. In addition it helped student to understand material in video files. In other words it organized students learning need (Sha, Looi, Chen, \& Zhang, 2012). It provided not only material for learning but also facilitated portfolio creation to demonstrate students understanding (Liu, Scordio, Renata, Navarete, Yujung, \& Lim, 2015).

Students got benefit from mobile phone use to facilitate their learning process. Their learning improved by the assistance of their mobile phone since they used mobile phone to access material by reading pdf file, playing video and creted project podcast. Mobile phone improved students learning process in their classroom (Liu, Scordio, Renata, Navarete, Yujung, \& Lim, 2015)

\section{CONCLUSION}

This study discussed mobile-assisted language learning (MALL) and focuses on English language. MALL has emerged as the branch of global movement in conducting mobile learning which serves as an umbrella project for educational purposes. This study is important in the context of Islamic higher education in Indonesia for implementing mobileassisted language learning. To date, the issue of MALL has not been studied exensively in Indonesian Islamic Higher Education. This study might initiates the development of MALL for English learning in Indonesian Islamic higher education context. 
The lack of research in MALL should be adressed to find out new way that propose promising method in delivering english. Education should respond to this emerging technology to reap the benefit they offer in supporting learning and teaching process.

This study has shown that students had positive perception toward their mobile phone for supporting their classroom activities. They also showed their engagement in using mobile phone to support classroom activities and English learning activities. There were several activities that students performed in reaping benefit of mobile phone to support classroom activities and English learning. Using offline dictionary, operating PDF reader, playing audio file and recording their video project using their mobile phone were the examples.The findings of this study have confirmed and supported previous research on MALL in an effort to offers some brand new approach in English learning activities by the existence of mobile phone. To support their learning experience, mobile phone offers many benefit that students can gain in supporting classroom activities and English learning.

It is expected that this approach and method of mobile english learning will be studied further in Islamic higher education context to propose a promising solution in english learning. Future studies should conduct in depth and large scale in investigating how mobile english learning implemented. With largest sample and the result might be generalizeabe.

\section{REFERENCES}

Al-Fahd, F. (2009). Students' Attitude and Perception Toward the Effectiveness of Mobile Learning in King Saud University, Saudi Arabia. The Turkish Online Journal of Educational Technology (8) 2 , 111-119.

Bull, G., \& Thompson, A. (2004). Establishing Framework for Digital Images in the School Curriculum. Leading and Learning with Technology (31) 8 , 14-17.

Corbeil, J. R., \& Valdes Corbeil, M. (2007). Are You Ready for Mobile Learning? EDUCAUSE Quarterly (30) 2 , 51-58.

Ducate, L., \& Lomicka, L. (2013). Going Mobile: Language Learning with an I-Pod Touch in Intermediate German and French Class. Foreign Language Annals (46) 3 , 445-468.

Gromik, N. (2012). Cell Phone Video Recording Feature as a Language learning Tool: A Case Study. Computer \& Education, 223-230. 
Hussain, I., \& Adeeb, M. (2009). Role of Mobile Technology in Promoting Campus-wide Learning Environment . Turkish Online Journal of Educational Technology (8)3 , 4857.

Kee, C. L., \& Samsudin, Z. (2014). Mobile Devices: Toys or Learning Tools for the 21st Century Teenagers? TOJET: The Turkish Online Journal of Educational Technology (13) $3,107-122$.

Kennedy, D. M. (2014). M-Learning to Suort Learning English in Hongkong University. MERLOT Journal of Online Learning and Teaching (10) 4 , 640-655.

Khabiri, M., \& Khatibi, M. B. (2013 ). Mobile-Assisted Language Learning: Practices Among Iranian EFL Learners. European Online Journal of Natural and Social Science (2) 2 , 176-190.

Lee, H., Lee, W. B., \& Kweon, S. C. (2013). Conjoint Analysis for Mobile Devices for Ubiquitous Learning in Higher Educatio: The Korean Case. TOJET (12) 1 .

Lenhart, A. (2015). Teens, Social Media \& Technology Overview 2015. Pew Research Centre's Interne \& American Life Project.

Liu, M., Scordio, R., Renata, G., Navarete, C., Yujung, K., \& Lim, M. (2015). A Look at Research on Mobile Learning in K-12 Education from 2007 to the Present . Journal of Research on Technology in Education (46) 4 , 325-372.

Looi, C., Seow, P., Zhang, B., So, H., Chen, W., \& Wong, L. (2010). Leveraging Mobile Technology for Sustainable Seamless Learning: A Research Agenda. British Journal of Educational Technology (41) 2 , 154-169.

Madden, M., Lenhart, A., Duggan, M., Cortesi, S., \& Gasser, U. (2013). Teens and Technology 2013. Pew Internet \&American Life Project .

Markett, C., Sanchez, I. A., Weber, S., \& Tangey, B. (2006). Using Short Message Service to Encourage Interactivity in the Classroom. Computers and Education , 280-293.

Nisbet, D., \& Austin, D. (2013). Enhancing ESL Vocabulary Development Through the Use of Mobile Tehnology. Journal of Adult Education (42) 1, 1-7.

Oyewusi, F., \& Ayanlola, A. O. (2014). Effect on Mobile Phone Use on Reading Habit of Private secondary School Student in Oyo State Nigeria. School Libraries Worldwide (20) $1,116-127$. 
Pegrum, M., Oakley, G., \& Faulkner, R. (2013). Schools Going Mobile: A Study of the Adoption of Mobile Handheld Technologies in Western Australian Independent Schools. Australian Journal of Educational Technology (29) 1 .

Pelleg, D., Savenkov, D., \& Agichtein, E. (2013). Touch Screeen for Touchy Issue. ICMSW 2013 .

Plester, B., Wood, C., \& Joshi, P. (2009). Exploring the Relationship Between Children's Knowledge of Text Message Abbreviation and School Literacy Outcomes. British Journalof Developmental Psycholog (27) 1 , 145-161.

Prensky, M. (2001). Digital Natives, Digital Immigrants. On The Horizon (9) 5 .

Sha, L., Looi, C., Chen, W., \& Zhang, B. H. (2012). Understanding MObile Learning from the Perspective of Self Regulated Learning. Journal of Computer Assisted Learning (28) $4,366-378$.

Smythe, S., \& Neufeld, P. (2010). Podcast Time. Negotiating Digital Literacies and Communities of Learning in a Middle Years ELL Classroom . Journal of Adolescent \& Adult Literacy (53) 6 , 488-496.

Steel, C. (2012). Fitting Learning Into Life: Language Students' Perspectives on Benefits of Using Mobile Apps. In M. M. Brown, \& T. Stewart, Future Challenges, Sustainable Futures. New Zealand: Wellington.

Thomas, K., \& Munoz, M. A. (2016). Hold the Phone! High School Students' Perception of Mobile Phone Integration in the Classroom . American Secondary Education (44) 3 , $19-37$.

Traxler, J. (2007). Defining, Discussing and Evaluating Mobile Learning: the Moving Finger Writes and Having Written. The International Review of Research in Open and Distance Learning (8) 2 , 9-24.

United Nations Educational, S. a. (2012). Turning on Mobile Learning: Global Themes. Unesco Working Paper Series on Mobile Learning .

Wu, W., Wu, Y., Chen, C., Kao, H., Lin, C., \& Haung, S. (2012). Review of Trends from Mobile Learning Studies: A MeaAnalysis. Computers in Education (59)2, 817-27. 
REGISTER JOURNAL, Language \& Language Teaching Journals Vol. 10, No. 1, 2017, pp.12-28 